\title{
Diversity and abundance of nematodes in soil treated with solarization treatments
}

\author{
ASTRI HARNOV PUTRI", SIWI INDARTI, TRI HARJAKA \\ Department of Plant Protection, Faculty of Agriculture, Universitas Gadjah Mada. Jl. Flora No. 1, Bulaksumur, Sleman 55281, Yogyakarta, Indonesia. \\ Tel.: +62-274-563062, 901290, Fax.: +62-274-563062, 519717, `email: astriharnovputri@gmail.com.
}

Manuscript received: 24 January 2021. Revision accepted: 9 June 2021.

\begin{abstract}
Putri A H, Indarti S, Harjaka T. 2021. Diversity and abundance of nematodes in soil treated with solarization treatments. Biodiversitas 22: 2612-2618. Solarization is a tillage cultivation technique that influences the presence of nematodes in agricultural land. This research aims to determine the solarization effect on soil temperature and nematode abundance and diversity in the soil. Observations on species, diversity, and abundance of the nematodes were performed at the Nematology Laboratory, Department of Plant Pests and Diseases, Faculty of Agriculture, Gadjah Mada University. A completely randomized design (CRD) was used with six treatments and three replications. Meanwhile, the treatment groups were based on solarization duration (in days) on the soil which includes A(3), B(7), C(14) D (30), and K0 (control, without solarization) and K1 ( control, farmer treatment). Field observations were performed to measure soil temperature, moisture, and $\mathrm{pH}$. Nematodes were analyzed in the laboratory to determine the genus, abundance, and diversity. Furthermore, extracted plant-parasitic nematodes were isolated by using the whitehead tray method while the entomopathogenic group was isolated using the baiting method. The results showed the differences in tillage treatment and solarization affect soil temperature (diversity and abundance). A polynomial regression model explained the relationship between increased solarization time and soil temperature. The highest soil temperature was found in cultivated land and solarization land for 14 days $\left(41.0^{\circ} \mathrm{C}\right)$ and the lowest was in the treatment of farmers $\left(33.67^{\circ} \mathrm{C}\right)$. The lowest abundance was found at 14 days solarization, namely 286 individuals $/ 100 \mathrm{~g}$, and the diversity index value of 1.37 . The highest diversity index was found in the treatment of farmers with an index value of 1.75 . The solarization treatment is best applied in the field for 14 days.
\end{abstract}

Keywords: Soil solarization, temperature, diversity and abundance of nematodes.

\section{INTRODUCTION}

Nematodes have an important role in soil agriculture. Nematodes have great economic benefits of both harmful and useful effects (Hailu and Hailu 2020). Plant-parasitic nematodes can cause massive damage to crops (Cotton et al. 2014). Plant-parasitic nematodes are one of the pests that can affect production in horticultural, food, and plantation crops. Plant-parasitic nematodes live and develop in plant tissue. Parasite nematodes can migrate from infected plants to other plants through the water around their host plants. Some examples of nematodes that are plant parasites are Meloidogyne sp. also called rootknot nematodes. One of the host plants of the nematode Meloidogyne sp. is a tomato plant. The specific symptoms of the attack can cause a knot or swelling of the roots (Mutala'liah et al. 2019).

Plant parasitic nematodes cause damage to plant parts such as leaves, stems, and roots. Most nematodes are found to attack the roots of plants. Nematodes in the roots caused the growth of plants is abnormal and the density of the nematode population affects plant growth (Kayani et al. 2017). Citrus nematode (Tylenchulus semipenetrans) causes severe damage to citrus. The nematode build-up was the maximum at the lower inoculum level and an inverse relationship was observed between the reproduction factor and inoculum densities of the nematode. Roots function as transporters of nutrients to the plant tissue above the soil surface. If nematodes attack the roots, the normal root system will be reduced, causing the transport file network to experience interference. Roots that are disturbed by the presence of nematodes cause the plant to wither easily (Irshad et al. 2012).

Farmers use various control techniques to solve the problem of nematodes in the soil. One of them is solarization method. According to Candido et al. (2011), soil solarization is a technique that utilizes solar radiation and aims to increase soil temperature by using clear polyethylene sheets. When combined with an aerobic disinfestation of soil, solarization can be used as an alternative to control pathogens and parasitic nematodes in the soil (Butler et al. 2012). Furthermore, Candido et al. (2008) stated that nematode recolonization could be hampered provided soil solarization is being carried out every two to three years. Hence, sustainable solarization treatment progressively reduces the population densities and prevents soil recolonization by nematodes.

Apart from parasitic nematodes, entomopathogenic nematodes were also found in agricultural land. The presence of entomopathogenic nematodes will benefit agricultural ecosystems because they can function as a biological control agent. The diversity of types of parasitic nematodes and entomopathogenic nematodes in an ecosystem is influenced by temperature. Solarization treatment on tillage will affect temperature. Several types of nematodes can survive and reproduce at certain 
temperatures. The research results of Glazer and Salame (2000) proved entomopathogenic nematodes can survive temperatures up to $45^{\circ} \mathrm{C}$. Solarization treatment is thought to affect the presence of species, population, and diversity of nematodes in agricultural land. Research has been carried out to determine the effect of tillage treatment using solarization techniques on soil temperature, population abundance, and nematode diversity in the soil.

\section{MATERIALS AND METHODS}

\section{Research location}

The study was conducted from July to November 2020 in Banyudono Village, Dukun Sub-District, Magelang Regency, Central Java. Observations on nematode genus, diversity, and abundance were carried out at the Nematology Laboratory, Department of Plant Pests and Diseases, Faculty of Agriculture, Gadjah Mada University.

\section{Tillage and solarization treatment}

Land preparation was done by cultivating the soil and loosening it until it was ready for planting. Transparent plastic with a thickness of $0.25 \mathrm{~mm}$ was installed by covering all the soil plots as an experimental unit. The soil was turned over and watered before were covered with clear plastic. Solarization time duration of the soil was 3, 7, 14, and 30 days. Meanwhile, control without solarization and farmer treatment (without treatment, covered with clear plastic, but silver plastic mulch is used, directly before planting until harvest).

A completely randomized design (CRD) was used as the research method while treatment was according to variable solarization duration. The 0 day solarization treatment and tillage were used by farmers as controls. Meanwhile, each treatment was replicated three times. The notation for each treatment was allotted as $\mathrm{K} 0$ for control without solarization and K1 for farmers' treatment. Also, treatments were carried out in groups denoted as A, B, C, and $\mathrm{D}$ with the duration of $3,7,14$, and 30 days, respectively, while the plot $\left(1 \times 2 \mathrm{~m}^{2}\right)$ layouts were randomly executed on the field. Solarization was made via loosened soil, irrigated, and covered with transparent polyethylene plastic. The closure duration was adjusted to the duration of solarization treatment.

Temperature, moisture, and $\mathrm{pH}$ were measured after solarization treatments. These parameters were measured with a soil survey instrument (Mediatech Soil Survey Instrument Digital 4 in 1 Backlight) by sticking it in the treated soil for 10 seconds. The tools are first fixed and then stuck into the ground vertically; hence, the temperature, moisture, and $\mathrm{pH}$ will appear.

\section{Extraction, isolation, identification, analysis of nematode diversity and abundance}

The nematode diversity and abundance were observed from solarized soil samples. The soil was taken from the treatment field randomly with approximately $200 \mathrm{~g}$ at a 10 $20 \mathrm{~cm}$ depth from the surface. Also, samples were placed in a labeled clear plastic bag measuring $20 \times 34 \mathrm{~cm}^{2}$ and afterward taken to the laboratory for extraction. Plantparasitic nematodes were extracted using the whitehead tray method (Kaya and Stock 1997), while entomopathogenic nematodes were isolated using the baiting method (Cowles et al. 2005).

\section{Whitehead tray method for the extraction and isolation of parasitic nematodes}

Soil samples from the field were isolated and extracted using a modified whitehead tray method (Kaya and Stock 1997). In this procedure, a whitehead tray was prepared while tissue paper was placed on it. Furthermore, the soil from the field $(100 \mathrm{~g})$ was afterward placed on the filter tray and leveled with water until it touched the surface of the filter paper. Soil that had been submerged with water was left for 24 hours at room temperature to isolate resident nematodes. Moreover, the soaked water resulting from nematode isolation was made into a suspension and deposited for 15 minutes. The suspension result was deposited in water, which contains nematodes with a gradually reduced volume until the suspension was set at $\pm 55 \mathrm{ml}$. A total of $5 \mathrm{~mL}$ suspension was taken and observed under a microscope binocular (Olympus CX-22), to identify the nematode genus and abundance.

\section{Baiting method for entomopathogenic nematode isolation}

Soil samples were isolated using the baiting method to obtain entomopathogenic nematodes. The soil was placed into a bottle until it reached half of its volume (Cowles et al. 2005). Bait insects (Tenebrio molitor) wrapped in gauze were placed in a bottle and gradually filled to the brim with soil. Afterward, the soil and bait insect larvae contained in the bottle were left for 7 days. The larvae were then transferred to a petri dish and left for 3 days after which the dead ones were filtered and placed on a buffer in a closed jar. The jar was filled with water until it touched the paper's edge and then incubated for 14 days. Entomopathogenic nematodes that moved into distilled water are those ready to be harvested. Nematodes were identified based on morphology and their abundance was then calculated.

Nematode identification was done based on morphological characteristics. The main characters were the body shape, the body length, part of the oral cavity (presence or absence of stylet, stylet type), the shape and length of the esophagus, the tail shape. The recovered nematodes were observed under microscope binocular (Olympus CX-22) and then identified by using a key on the web nematode.unl.edu.and book Key to Genera of PlantParasitic Nematodes (Mai and Lyon 1975; Hazir et al. 2004).

\section{Data analysis}

The data for soil temperature with the abundance and diversity of nematode were analyzed using the analysis of variance ANOVA test. Meanwhile, the LSD test was performed at a 5\% level whenever the result was significantly different. The analysis was performed using the Stat 8.0 program (a statistical program for windows), while the relationship between solarization, temperature, and abundance was depicted in graphical form. 
Furthermore, regression analysis was used to determine the relationship between solarization treatments and soil temperature. This regression model was based on the $\mathrm{R}^{2}$ value hence, an $\mathrm{R}^{2}$ value close to 1 was the most appropriate model used to determine the formula of the relationship. Regression analysis was performed using the Excel program (Excel for Windows 2019).

Nematode abundance and diversity found at sample locations were analyzed by using a diversity index $(\mathrm{H}$ index). The diverse genus of nematode genus can be measured by using a diversity index that refers to the Shannon-Wiener (Krebs 1989). Meanwhile, the ShannonWiener diversity index equation is as follows:

$$
\mathrm{H}^{\prime}=-\sum_{\mathrm{i}=1}^{\mathrm{s}}\left[\left(\frac{\mathrm{ni}}{\mathrm{N}}\right) \ln \left(\frac{\mathrm{ni}}{\mathrm{N}}\right)\right]
$$

Where:

$\mathrm{H}^{\prime}$ : Shannon-Wiener Diversity Index

$S$ : Number of species

ni : number of individual species-i

$\mathrm{N}$ : Number of individuals of all species.

\section{RESULTS AND DISCUSSION}

\section{Effect of solarization treatment on soil temperature}

The observations on soil temperature treated periodically with solarization as well as the control and farmers treatment showed significantly different results $(\mathrm{P}$ $=0.0012$ ) $($ Table 1$)$. The treated solarized soil moisture was the same $(40 \%)$. This was due to the simultaneous performance of the watering treatment. The level of soil acidity $(\mathrm{pH})$ was also the same in each treatment.

The highest temperature in the solarized soil was at 14 days $\left(41^{\circ} \mathrm{C}\right)$. However, this was not significantly different with 7 days $\left(39.67^{\circ} \mathrm{C}\right)$ but was significantly different from other treatments. Therefore, it can be seen that there was an increase in soil temperature when soil solarization duration was increased. Also, this increasing temperature trend progressed from 3,7 to 14 days, but the temperature decreased with further solarization duration. As observed, the temperature was lower for soil solarized for 30 days than those for 3, 7, and 14 days.
There was a relationship between solarization duration, temperature, and abundance, which was described in terms of the three parameters. The relationship between solarization duration and temperature based on regression analysis is illustrated in Figure 1 and Table 2.

The relationship between solarization duration and soil temperature includes (i) linear, (ii) polynomial and (iii) exponential (Figure 1). Furthermore, the closest relationship was polynomial with the value $R^{2}=0.9$ or close to 1 , and the equation was $y=-0.0288 x^{2}+0.8973 x+$ 34.322. Compared with other forms of relationships, the $\mathrm{R}^{2}$ value was lesser than 1 and close to 0 indicating no relationship. But in this observation, the polynomial regression equation with a value of $\mathrm{R}^{2}=0.9077$ means that there is a relationship between solarization treatment time and temperature (Table 2).

The relationship between solarization duration and soil temperature was modeled as $\mathrm{y}=$ temperature and $\mathrm{x}$ is the duration or duration of the solarization. Meanwhile, the polynomial relationship is a form in which the regression relationship is non-linear. Soil temperature tends to increase with increasing solarization duration, but the increase was non-linear. The increase occurred with increasing solarization duration up to a certain point. Furthermore, there was a decrease in soil temperature, although the solarization duration continues to increase. The purpose of regression analysis was to model the expected value of the dependent variable (y) in terms of the independent variable $(\mathrm{x})$. This means that the value of $\mathrm{x}$ (solarization duration ) can determine the soil temperature (y). Therefore, the solarization duration ( $\mathrm{x}$ value) can be changed or adjusted to get the required temperature (y value).

Table 1. The temperature and $\mathrm{pH}$ of solarized soil with different duration of time, control, and farmer treatment

\begin{tabular}{lcc}
\hline Treatment solarization & Soil temp. $\left({ }^{\circ} \mathbf{C}\right)$ & pH \\
\hline 14 days & $41.00 \mathrm{a}$ & 7.0 \\
7 days & $39.67 \mathrm{a}$ & 7.0 \\
3 days & $37.00 \mathrm{~b}$ & 7.0 \\
30 days & $35.33 \mathrm{bc}$ & 7.0 \\
Control (without solarization) & $35.33 \mathrm{bc}$ & 7.0 \\
Farmer treatment & $33.67 \mathrm{c}$ & 7.0 \\
\hline
\end{tabular}

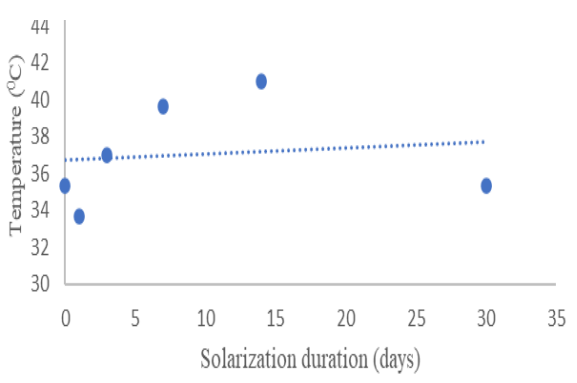

A

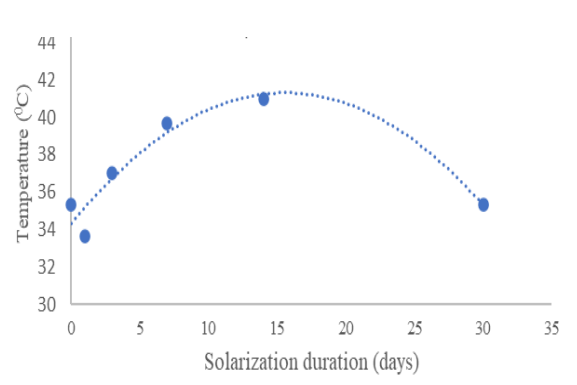

B

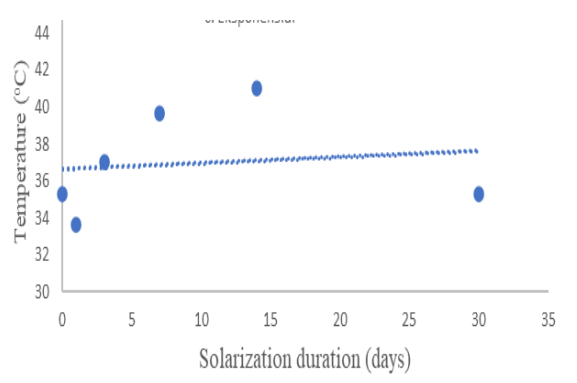

C

Figure 1. The regression form of the relationship between temperature and solarization duration. A. Linear, B. Polynomial, C. Exponential 
Table 2. The equation form for the relationship between solarization duration and soil temperature.

\begin{tabular}{lll}
\hline $\begin{array}{l}\text { Regression } \\
\text { relationship form }\end{array}$ & Formula & $\begin{array}{l}\text { Value } \\
\text { of } \mathbf{R}^{\mathbf{2}}\end{array}$ \\
\hline $\begin{array}{l}\text { Linear } \\
\text { Polynomial }\end{array}$ & $\mathrm{y}=0.0327 \mathrm{x}+36.701$ & 0.0175 \\
Exponential & $\mathrm{y}=-0.0288 \mathrm{x}^{2}+0.8973 \mathrm{x}+34.322$ & 0.9077 \\
\hline
\end{tabular}

Temperature affects the presence and abundance of nematodes in the soil. The higher the temperature, the lower the abundance of the nematode population (Figure 2). The highest temperature was at 14 days of solarization $\left(41.0^{\circ} \mathrm{C}\right)$, with the lowest nematode population $(286$ individuals $/ 100 \mathrm{~g})$, followed by at 7 days $\left(39.67^{\circ} \mathrm{C} ; 300.68\right.$ individuals $/ 100 \mathrm{~g}$ ). While, the solarization treatment for 30 days and the control had the same temperature of $35.33^{\circ} \mathrm{C}$, and the nematode population between the two treatments were not significantly different. The lowest temperature was found in the treatment of farmers with $33.67^{\circ} \mathrm{C}$ and a nematode population of $363.01 / 100 \mathrm{~g}$.

\section{Population abundance and nematode diversity in} solarized soil, without solarization, and farmer treatment

In different solarization treatments, different genus and abundance of nematodes were found. There are several genera of nematodes that were not found in solarization treatments but were found in the control and treatment of farmers. The varieties of nematodes found were identified down to their genus based on morphological characteristics (type of stylet, posterior). Furthermore, the abundance of each genus in all treatments can be seen in Table 3

The population of nematode found in each solarized soil at different durations showed significant differences at the $5 \%$ level $(\mathrm{P}=0.000)$. All treatments, with or without solarization including those by the farmers had a population that ranged from 286 to 579.34 nematodes (Figure 3).

The highest nematode abundance was in the solarized soil for 3 days (579.34 individuals /100g) significantly different between treatments. Also, the population was seemingly lower in soil treated for 14 days (286 individuals $/ 100 \mathrm{~g}$ ). Meanwhile, the abundance of nematodes in the land is thought to affect plants especially when there are more resident parasitic genus than other breeds such as saprophages or non-parasitic nematodes. Population abundance and diversity of nematode genus determined the diversity index value.

The diversity of nematodes in solarized soil treated at intervals with or without solarization and those treatments by farmers showed significant differences. Therefore, results analysis of soil diversity treated with solarization at intervals indicated that the diversity index was significantly different $(\mathrm{P}=0.0034)$ (Table 3$)$.

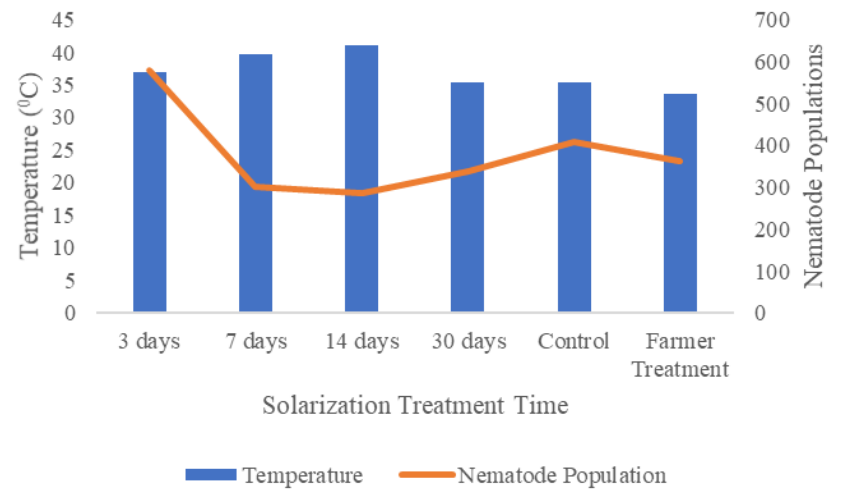

Figure 2. Relationship between solarization duration, soil temperature, and nematode abundance

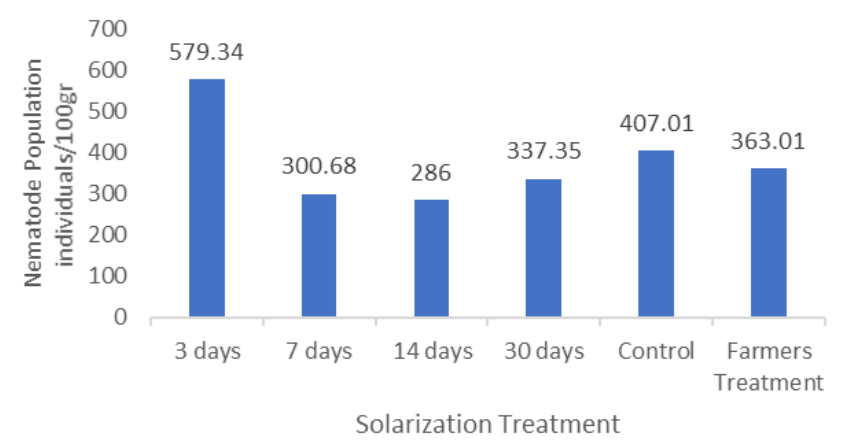

Figure 3. Nematode populations on solarized soil at different durations. control without solarization and farmer treatment

Table 3. Genus and abundance of nematode populations found in soil solarization treatments

\begin{tabular}{lcccccc}
\hline \multirow{2}{*}{ Genus } & \multicolumn{3}{c}{ Abundance population of nematodes in soils with different solarization treatments (individuals/100g) } \\
\cline { 2 - 7 } & 3 days & 7 days & 14 days & 30 days & Control & Farmers treatment \\
\hline Aphelenchoides & 36.67 & 3.67 & 3.67 & 3.67 & 69.67 & 99.00 \\
Helicotylenchus & 80.67 & 124.67 & 91.67 & 201.67 & 0.00 & 11.00 \\
Meloidogyne & 172.33 & 73.33 & 44.00 & 58.67 & 157.67 & 36.67 \\
Paratylenchus & 0.00 & 0.00 & 0.00 & 0.00 & 3.67 & 25.67 \\
Pratylenchus & 0.00 & 3.67 & 29.33 & 0.00 & 18.33 & 33.00 \\
Tylenchus & 55.00 & 14.67 & 44.00 & 25.67 & 69.67 & 80.67 \\
Heterorhabditis & 201.67 & 77.00 & 73.33 & 22.00 & 3.67 & 29.33 \\
Steinernema $^{*}$ & 33.00 & 3.67 & 0.00 & 25.67 & 84.33 & 47.67 \\
\hline
\end{tabular}

Note: *entomopathogenic nematode 
Table 4. The diversity index of nematodes on solarized soils without solarization. and farmer treatment

\begin{tabular}{lc}
\hline Treatment solarization & Diversity index $\left(\mathbf{H}^{\prime}\right)$ \\
\hline 3 days & $1.18 \mathrm{~b}$ \\
7 days & $1.38 \mathrm{ab}$ \\
14 days & $1.37 \mathrm{ab}$ \\
30 days & $1.05 \mathrm{~b}$ \\
Without solarization & $1.50 \mathrm{ab}$ \\
Farmer treatment & $1.75 \mathrm{a}$ \\
\hline
\end{tabular}

Note: Figures followed by the same lowercase letters in the same column indicate insignificant differences based on the LSD test at the $5 \%$ level.

In table 4 , it can be seen that the nematode diversity index was significantly different in the 3 days treatment from the farmer's treatment. The highest diversity index was found in the treatment of farmers (1.75), while the lowest diversity is at 30 days of treatment (1.05). These values were determined by the number of genus present and the abundance of nematodes in the soil.

\section{Discussion}

Soil treatment with solarization is one of the cultivation techniques in an agroecosystem. Solarization or soil tillage treatment mostly uses clear plastic. The application of this technique at different intervals is expected to improve soil temperature. While the moisture levels observed for the soil treated were the same. Watering was carried out simultaneously on all treated fields. Similarly, the soil $\mathrm{pH}$ shows the same value for each cultivated and solarized soil $(\mathrm{pH}$ 7.0). The difference was in the soil temperature that had been confirmed from five research treatments. The highest soil temperature occurred at 14 days of solarization. However, it was not significantly different from the 7 days treatment. This suggests that solarization treatment for 1 to 2 weeks can increase soil temperature. Simmons et al. (2013) previously proved that solarization alters soil temperature. Solarization treatment using a clear plastic trap can increase soil temperature from passive solar heating.

The regression relationship between solarization duration and soil temperature was polynomials (Fig, 1). Meanwhile, polynomial regression in this research is different from linear regression. Furthermore, the analysis was carried out by adding up the effect of the variables, including the duration of solarization as $\mathrm{x}$ to predict the value or soil temperature. The value of $y$ increased as the value of $\mathrm{x}$ increases, but the increase was only up to a certain point. Also. the increase in soil temperature was followed by increasing solarization duration. However, this increase only proceeded to a certain point after which temperature began to decrease. It is assumed that in the solarization treatment 3,7 , and 14 days the soil conditions are still loose so that the reception of the sun's temperature in these conditions is still effective. In contrast to the 30days solarization treatment, the soil conditions have begun to solidify. Soil temperature factors affect the life cycle and behavior of nematodes living in the soil (Munteanu 2017). Solarization can increase soil temperature causing death to resident nematodes. Parasitic nematodes die when the highest temperature during solarization is achieved at or nearby the soil surface. However, soil temperature decreases with increasing depth (Stapleton 2000).

In this research, the temperature increased to $41^{\circ} \mathrm{C}$ with solarization treatment for 14 days and gradually decreased afterward. The relationship between temperature and solarization duration was polynomial $\left(\mathrm{R}^{2}=0.98\right)$. According to Nelly et al. (2005), predictions or models expressed by polynomial regression show that the value of $\mathrm{y}$ is determined by $\mathrm{x}$ and the power $\mathrm{x}$. Furthermore. modeling the effect of solarization duration on temperature as described by the polynomial regression equation showed that the increase in temperature occurred by increasing the solarization duration to a certain point, it remains constant or decreases gradually.

The differences in soil temperature are thought to have contributed to the presence of nematodes. All genera of parasitic nematodes were found in the soil treated with different solarization. Except for Pratylenchus parasite nematodes were not present in the 3 days solarization treatment, and Paratylenchus nematodes were only in the control treatment and the farmer's treatment. According to Triman and Mulyadi (2001), parasitic nematode plants can live in temperatures between $15-30^{\circ} \mathrm{C}$ whereas at low temperatures around $5-15^{\circ} \mathrm{C}$ and very high temperatures ranging from $30-40^{\circ} \mathrm{C}$ these organisms become inactive. Similarly, entomopathogenic nematodes can also live and develop at temperatures above $25^{\circ} \mathrm{C}$ because these particular genera become inactive resulting in reduced effectiveness in controlling the host. Temperature affects lipids in entomopathogenic nematodes. Lipids represent the main source of energy in entomopathogenic nematodes (Andalo et al. 2011).

Based on Gaugler and Kaya (1990), the suitable water temperature for nematodes was $20.9+5.9^{\circ} \mathrm{C}$, while the soil temperature was $20.1+4.5^{\circ} \mathrm{C}$. In the solarization treatment, entomopathogenic nematodes were found, namely Steinernema and Heterorhabditis. Heterorhabditis nematodes were found in all solarization treatments, while Steinernema nematodes were not found in the 14 days solarization treatment. Soil temperature in the 14 days solarization treatment was $41^{\circ} \mathrm{C}$, higher than the other solarization treatments. The study by Glazer and Salame (2000) showed the ability of entomopathogenic nematodes to survive and withstand the highest temperature conditions.

The abundance of nematode populations had different results in each solarization treatment. As shown in Table 3, some nematode genera were not found in certain treatments. Paratylenchus nematodes were not found in solarization treatments of $3,7,14$, and 30 days. These nematodes were found in the control and treatment of farmers. In the treatment of farmers, all types of nematodes were found. The highest nematode diversity was found in the treatment of farmers and it was not different from the control. The lowest nematode diversity was found in the 30 days solarization treatment but it was not significantly different from the 3, 7, and 14 days solarization treatment. Biotic and abiotic factors influence the diversity of 
nematodes in the land. Among these factors that influence it are soil temperature and humidity (Sagita et al. 2017).

In conclusion, differences in tillage treatment and solarization affect soil temperature. The relationship between increasing solarization time and soil temperature is described by a polynomial regression model. The highest soil temperature was found in cultivated and solarized land for 14 days at $41.0^{\circ} \mathrm{C}$ and the lowest in the treatment of farmers, namely $33.67^{\circ} \mathrm{C}$. Solarization treatment can best be applied in the field for 14 days. The nematode genera found in the observation field include; Aphelenchoides, Helicotylenchus, Meloidogyne, Paratylenchus, Pratylenchus, Tylenchus, Heterorhabditis, and Steinernema.

\section{ACKNOWLEDGEMENTS}

The authors thank the Directorate for Community Service. Universitas Gadjah Mada. Yogyakarta. Indonesia for the grant through community engagement program with contract number 677/UN1/DPM/YANMAS/PM/2020.

\section{REFERENCES}

Andaló V, Moino A, Maximiniano C, Campos VP, Mendonca LA. 2011 Influence of temperature and duration of storage on the lipid reserves of entomopathogenic nematodes. J Rev Colom Ent 37 (2): 203-209.

Anita B. 2012. Crucifer vegetable leaf wastes as biofumigants for the management of root-knot nematode (Meloidogyne hapla Chitwood) in celery (Apium graveolens L.). J Biopest 5: 111.

Butler DM., Kokalis-Burelle N, Muramoto J, Shennan C, McCollum TG, Rosskopf EN. 2012. Impact of anaerobic soil disinfestation combined with soil solarization on plant-parasitic nematodes and introduced inoculum of soilborne plant pathogens in raised-bed vegetable production. J Crop Prot 39: 33-40. DOI: 10.1016/j.cropro.2012.03.019

Candido V, d'Addabbo T, Basile M, Castronuovo D, Miccolis V. 2008 Greenhouse soil solarization: effect on weeds. nematodes. and yield of tomato and melon. J Agro Sustain Dev 28 (2): 221-230. DOI: 10.1051/agro: 2007053.

Candido V, D’Addabbo T, Miccolis V, Castronuovo D. 2011. Weed control and yield response of soil solarization with different plastic films in lettuce. J Sci Hortic 130 (3): 4 91-497. DOI: 10.1016/j.scienta.2011.08.002

Cotton JA, Lilley CJ, Jones LM, Kikuchi T, Reid AJ, Thorpe P, Tsai IJ, Beasley H, Blok V, Cock PJA, Akker SE, Holroyd N, Hunt M, Mantelin S, Naghra H, Pain A, Rius JEP, Zarowieck M, Berriman M, Jones JT, Urwin PE. 2014. The genome and life-stage specific transcriptomes of Globodera pallida elucidate key aspects of plant parasitism by a cyst nematode. J Genome Bio 15 (3): 1-17. DOI: 10.1186/gb-2014-15-3-r43.

Cowles RS, Polavarapu S, Williams RN, Thies A, Ehlers RU. 2005. Soft fruit applications. In: Grewal PS, Ehlers RU, Shapiro-Ilan DI (eds.). Nematodes as Biocontrol Agents. CABI, Wallingford, UK.

Gaugler R, Kaya HK. 1990. Entomopathogenic Nematodes in Biological Control. CRC Press. Boca Raton, FL.

Glazer I, Salame L. 2000. Osmotic survival of the entomopathogenic nematode Steinernema carpocapsae. Biol Cont 18 (3): 251-257. DOI: 10.1006/bcon.2000.0814

Hailu FA, Hailu YA. 2020. Agro-ecological importance of nematodes (round worms). Acta Sci Agric 4 (1): 156-162.

Hazir S, Kaya HK, Stock SP, Keskin N. 2004. Entomopathogenic nematodes (Steinernematidae and Heterorhabditidae) for biological control of soil pests. J Turkish Biol 27 (4): 181-202.

Irshad U, Mukhtar T, Ashfaq M, Kayani MZ, Kayani SB, Hanif M, Aslam S. 2012. Pathogenicity of citrus nematode (Tylenchulus semipenetrans) on Citrus jambhiri. J Anim Plant Sci 22 (4): 10141018.

Kaya HK, Stock SP. 1997. Techniques in insect nematology. In: L. A. Lacey (eds) Manual of Techniques in Insect Pathology. Academic Press. London, UK.

Kayani MZ, Mukhtar T, Hussain MA. 2017. Effects of southern root-knot nematode population densities and plant age on growth and yield parameters of cucumber. J Crop Prot 92: 207-212. DOI: 10.1016/j.cropro.2016.09.007.

Krebs CJ. 1989. Ecological Methodology. Second Edition. An Imprint of Addition Wesley Longmen, New York.

Mai WF, Lyon HH. 1975. Pictorial key to genera of plant-parasitic nematodes. Comstock, Ithaca.

Munteanu R. 2017. The Effects Of Changing Temperature And Precipitation On Free-Living Soil Nematoda In Norway. [Thesis]. Lund University, Sweden.

Mutala'liah ML, Indarti S, Wibowo A. 2019. The prevalence and species of root-knot nematode which infect potato seed in Central Java, Indonesia. Biodiversitas 20 (1): 11-16. DOI: 10.13057/biodiv/d200102.

Nelly N, Habazar T, Syahni R, Sahari B, Buchori D. 2005. The functional response of the parasitoid Eriborus argenteopilosus (Cameron) to Crocidolomia pavonana (Fabricius) at different temperatures. Hayati J Biosci 12(1): 17-22. DOI: 10.4308/hjb.12.1.17.

Sagita L, Siswanto B, Kurniatun H. 2017. Study of diversity and density of nematodes in various land use systems in the Konto Sub-Basin. $\mathbf{J}$ Land Land Resou 1 (1): 51-60. [Indonesian]

Simmons CW, Guo H, Claypool JT, Marshall M N, Perano KM, Stapleton JJ, VanderGheynst JS. 2013. Managing compost stability and amendment to soil to enhance soil heating during soil solarization. $\mathbf{J}$ Waste Manag 33 (5): 1090-1096. DOI: 10.1016/j.wasman.2013.01.015.

Stapleton. JJ. 2000. Soil solarization in various agricultural production systems. J Crop Protect 19 (8-10): 837-841. DOI: 10.1016/S02612194(00)00111-3

Triman B, Mulyadi M. 2001. Control of root nematodes (Meloidogyne spp.) On beans with bacteria Pasteuria penetrans and solarization. J Indon Plant Prot 7 (1): 49-54. [Indonesian]

Yaqub F, Shahzad S. 2009. Effect of solar heating by polyethylene mulching on sclerotial viability and pathogenicity of Sclerotium rolfsii on mungbean and sunflower. Pakistan J Bot 41 (6): 3199-3205. 